\title{
Mitigating agricultural greenhouse gas emissions: A review of scientific information for food system planning
}

\author{
Tara L. Moreau, ${ }^{\mathrm{a}, *}$ Jennie Moore, ${ }^{\mathrm{b}}$ and Kent Mullinix ${ }^{\mathrm{c}}$
}

Submitted 18 April 2011 / Revised 4 July 2011 and 1 August 2011 / Accepted 2 September 2011 / Published online 20 March 2012

Citation: Moreau, T. L., Moore, J., \& Mullinix, K. (2012). Mitigating agriculture greenhouse gas emissions: A review of scientific information for food system planning. Journal of Agriculture, Food Systems, and Community Development, 2(2), 237-246.

http://dx.doi.org/10.5304/jafscd.2012.022.007

Copyright (C) 2012 by New Leaf Associates, Inc.

\begin{abstract}
Agriculture contributes significantly to anthropogenic greenhouse gases (GHGs), with estimates of agriculture's contribution ranging from $10 \%$ to $25 \%$ of total global GHG emissions per year. The science regarding mitigating (reducing and removing) GHGs through agriculture is conflicting and inconclusive. However, the severity and urgency of climate change and its potential effects on food security demonstrate that we must include mitigation within food system planning frameworks. In British Columbia, Canada, the provincial

\footnotetext{
a,* Corresponding author: Tara Moreau, Pacific Institute for Climate Solutions, University of British Columbia, Canada, 2060 Pine Street, Vancouver, British Columbia V6J 4P8 Canada; +1-604-783-8571; taramoreau@gmail.com

b Pacific Institute for Climate Solutions, School of Community and Regional Planning, University of British Columbia; jennielynnmoore@hotmail.com

${ }^{\mathrm{c}}$ Institute for Sustainable Horticulture, Kwantlen Polytechnic University, Surrey, British Columbia, Canada; kent.mullinix@kwantlen.ca
}

Note: Funding for this project was provided by the Pacific Institute for Climate Solutions. government has established significant GHG reduction targets for its agencies, and has called on local governments to reduce their carbon footprints through a charter and incentive, as well as through growth management legislation. At the same time, local governments, are giving increased attention to development of local/regional agrifood systems. However, GHG mitigation efforts do not yet seem to factor into local agri-food system discussions. Although frameworks for reporting agriculture GHGs exist, local government measurement of agriculture mitigation is hampered by a lack of agriculture GHG inventories, limited data availability, and the inherent variability in agriculture emissions and removals due to the dynamic nature of farm ecosystems. With the goal of informing local governments and food system planners on the importance of agriculture GHG mitigation, this paper (1) reviews the science of GHGs, (2) describes sources of agriculture GHG emissions and illustrates potential mitigation practices, (3) discusses the variability of agriculture mitigation science, (4) highlights the importance of agriculture GHG inventories, and (5) emphasizes the necessity for local agriculture mitigation strategies. 


\section{Keywords}

agriculture, carbon sequestration, climate change, food systems, greenhouse gas (GHG), GHG inventory, GHG mitigation, local governments

\section{Introduction}

The Earth's climate is changing in direct response to anthropogenic GHGs, as manifested in increasing global average air and ocean temperatures, melting of snow and ice, and rising sea levels (Intergovernmental Panel on Climate Change (IPCC), 2007a). In 2004, 77\% of total global anthropogenic emissions $\left(49,000 \mathrm{MtCO}_{2} \mathrm{e}\right)$ were from carbon dioxide $\left(\mathrm{CO}_{2}\right), 14 \%$ from methane $\left(\mathrm{CH}_{4}\right), 8 \%$ from nitrous oxide $\left(\mathrm{N}_{2} \mathrm{O}\right)$, and $1 \%$ from other GHGs (IPCC, 2007b). The global food system is estimated to contribute at minimum onethird of all global anthropogenic emissions, more than twice that of the transport sector (IPCC, 2007a; Scialabba \& Muller-Lindenlauf, 2010). Agriculture alone contributes between 10\% and $25 \%$ of annual GHGs, both directly and indirectly, through land-use changes, land management, and production practices (Scialabba \& MullerLindenlauf, 2010; Smith...Sirotenko, 2007). Methane, nitrous oxide, and carbon dioxide are considered the three ${ }^{1}$ most important GHGs emitted from agriculture (Smith...Sirotenko, 2007; Smith, Grant, Desjardins, Worth, Li, Boles, \& Huffman, 2010). In the coming decades, agriculture GHG emissions are expected to rise as the global population increases and as changes in diets (especially consumption of more animal protein) continue (Smith...Sirotenko, 2007).

The United Nations Framework Convention on Climate Change (UNFCCC) promotes mitigation and adaptation as two main options to address climate change. Mitigation involves reducing GHGs emitted into the atmosphere and removing atmospheric GHGs through the use of sinks

\footnotetext{
${ }^{1}$ Water vapor is an important GHG, but the effects of its emissions (especially from agriculture) are not well understood at this time, and therefore it is not included in this discussion. Refrigerants such as hydrofluorocarbons (HFCs) and perfluorcarbons (PFCs) are also associated with agriculture, but they are released in smaller quantities.
}

(carbon sequestration). Climate change adaptation for agriculture involves building resistance (the ability to resist the impact of a disturbance) and resilience (the ability to recover from disturbance) within agro-ecosystems, communities, and governance operations to prepare for climatic change and its impacts (Holt-Giménez, 2002; Pimm, 1984). Mitigation and adaptation differ in at least three ways including: (1) temporal and spatial scales at which the options are effective; (2) methods by which costs and benefits can be inventoried, estimated, and compared; and (3) stakeholders and governance drivers involved in their implementation (Klein, Schipper, \& Dessai, 2005). Finding synergies between the two response options is considered ideal. However, due to their differences, each response requires separate attention and individual action in order to properly respond to climate change. Although the importance of adaptation is recognized, the focus of this paper is on mitigation within agriculture.

Regionally appropriate improved agriculture practices can reduce the amount of GHGs entering the atmosphere (Scialabba \& Muller-Lindenlauf, 2010; Smith...Sirotenko, 2007), and carbon sequestration is considered a partial solution to short- and medium-term removal of atmospheric carbon (Hutchinson, Campbell, \& Desjardins, 2007; Lal, 2009; Morgan et al., 2010). However, the science of mitigating GHGs through agriculture is sometimes variable, conflicting, and inconclusive. The scientific uncertainties around mitigating GHGs in agriculture may imply the need to postpone action while additional knowledge and greater clarity are sought, but given the urgency of climate change, agriculture mitigation planning must be vigorously pursued and strategies implemented. In fact, despite these uncertainties, a number of long-term policy decisions to mitigate GHGs are being implemented by various levels of government around the world.

Climate change mitigation strategies within agriculture must consider and address regional environmental, economic and social priorities. In British Columbia, Canada, mandated climate policies are challenging local governments to achieve signifi- 
cant GHG reduction targets within their operations. Since 2008, local government attention has focused on where the greatest GHG reductions are perceived to exist, namely, transportation, waste, and buildings. At the same time, local and regional agri-food systems strategies are being pursued to achieve food security and public health goals. However, the merging of GHG emissions reductions and regional food system planning has been limited. With the goal of raising awareness of the necessity for agriculture GHG mitigation planning by local governments, the objective of this paper is to give an overview of the pertinent scientific information. Specifically, we (1) review the science around climate change and GHG emissions, (2) identify sources of agriculture emissions and illustrate potential mitigation practices, (3) discuss the uncertainties associated with agriculture mitigation, (4) describe agriculture GHG inventories, and (5) highlight the need for local governments to engage in measuring and monitoring agriculture emissions.

\section{Science of Greenhouse Gases (GHGs)}

Greenhouse gases are a group of trace substances in our atmosphere that absorb and emit infrared radiation emanating from the Earth's surface. If it were not for trace GHGs in our atmosphere, the surface temperature of Earth would be $-18^{\circ} \mathrm{C}$ (Jenkinson, 2010). However, since the start of the Industrial Revolution in the 1750s, human activities have substantially increased atmospheric concentrations of GHGs. For example, the atmospheric concentration of carbon dioxide $\left(\mathrm{CO}_{2}\right)$ has increased from 280 parts per million (ppm) in the 1750 s to $379 \mathrm{ppm}$ in 2005. Within the same time frame, methane $\left(\mathrm{CH}_{4}\right)$ concentrations have increased from 715 parts per billion (ppb) to 1774 $\mathrm{ppb}$, and nitrous oxide $\left(\mathrm{N}_{2} 0\right)$ has increased from about 270 ppb to 319 ppb (IPCC, 2007a).

A GHGs' ability to contribute to global warming, referred to as global warming potential (GWP), is determined by its atmospheric lifetime and capacity to trap heat over a given period of time. GWP compares the mass of a particular gas relative to the same mass of carbon dioxide. For example, evaluated over a 100-year time frame, one unit of $\mathrm{N}_{2} \mathrm{O}$ has a GWP 296 times that of one unit of
$\mathrm{CO}_{2}$, and $\mathrm{CH}_{4}$ has a GWP 23 times one unit of $\mathrm{CO}_{2}$ (Forster et al., 2007). To describe the flow of GHGs into the atmosphere, researchers use carbon dioxide equivalents $\left(\mathrm{CO}_{2} \mathrm{e}\right)$ as the unit of measure. The $\mathrm{CO}_{2} \mathrm{e}$ value is obtained by multiplying the total quantity (mass) of a gaseous emission by its GWP. $\mathrm{MtCO}_{2} \mathrm{e}$ is the standard measurement of the amount of $\mathrm{CO}_{2}$ emissions that are reduced or secluded from our environment, and stands for metric tonne (ton) carbon dioxide equivalent. A ton of carbon dioxide equals 2204.62 pounds of $\mathrm{CO}_{2}$ ("Common Questions About $\mathrm{MtCO}_{2}$," 2008).

\section{Sources of Agriculture GHG Emissions}

Methane: Methane emissions from agriculture are associated with the decomposition of organic materials (plant debris and animal wastes) in anaerobic (without oxygen) conditions, from ruminant livestock digestion (enteric fermentation in cattle, sheep, and goats), stored manures, and crops grown in flooded conditions (such as rice). $\mathrm{CH}_{4}$ emissions from animal waste can be reduced through improved storage and handling of waste (e.g., covering manure pits) and through the use of anaerobic digesters (Smith...Sirotenko, 2007). Decomposing manures also release $\mathrm{N}_{2} \mathrm{O}$, which complicates manure management mitigation strategies because certain practices that decrease $\mathrm{CH}_{4}$ may increase $\mathrm{N}_{2} \mathrm{O}$. Composting manures rather than leaving them as liquid slurry, for example, was found to decrease $\mathrm{CH}_{4}$ emissions but to increase $\mathrm{N}_{2} \mathrm{O}$ emissions (Paustian et al., 2004). $\mathrm{CH}_{4}$ emissions from enteric fermentation can be mitigated by dietary manipulation ${ }^{2}$ (such as replacing forages with concentrates [e.g., starch or fiber], improving pasture quality, optimizing protein intake, etc.), breeding for lower emitting animals, and using dietary additives (such as probiotics) that suppress bacteria that produce methane (Eagle, Henry, Olander, Haugen-Kozyra, Millar, \& Roberton, 2010; Smith...Sirotenko, 2007; Smith et al., 2008).

\footnotetext{
2 There is ongoing discussion about GHG mitigation by dietary manipulation of cattle due to differences in methodologies and regional practices. This discussion is beyond the scope of this paper.
} 
Nitrous Oxide: Nitrous oxide is released when bacteria mineralize nitrogenous substances in soils and manure pits, and when synthetic nitrogenous fertilizers applied to fields volatize into the atmosphere. Soil microorganisms produce $\mathrm{N}_{2} \mathrm{O}$ emissions through two microbial soil processes: nitrification (conversion of ammonium $\left[\mathrm{NH}_{4}{ }^{+}\right]$to nitrate nitrogen $\left[\mathrm{NO}_{3}\right]$ ) and denitrification (conversion of nitrate nitrogen $\left[\mathrm{NO}_{3}\right]$ to dinitrogen $\left.\left[\mathrm{NO}_{2}\right]\right)$. The most important conditions that affect $\mathrm{N}_{2} \mathrm{O}$ emissions from fields treated with fertilizers containing ammonium and nitrate include (1) environmental factors such as ambient temperature, soil oxygen concentrations, soil texture, and soil $\mathrm{pH}$, and (2) farm management and crop production practices such as fertilizer type used, application rate (the amount of ammonium $\left[\mathrm{NH}_{4}{ }^{+}\right]$ and nitrate $\left[\mathrm{NO}_{3}\right]$ present for nitrification and denitrification, respectively), timing and method of application, and type of crop species treated (with major differences between grasses, legumes, and annual crops) (IFA/FAO, 2001). Recommended practices to reduce $\mathrm{N}_{2} \mathrm{O}$ emissions from production agriculture activities include changing nitrogen fertilizer sources (e.g., changing from anhydrous ammonia or urea to slow-release fertilizers or biological sources), using nitrification inhibitors, minimizing $\mathrm{N}$ fertilizer rates, calibrating $\mathrm{N}$ fertilizer application to crop needs, and adjusting $\mathrm{N}$ fertilizer placement (Eagle et al., 2010; Scialabba \& MullerLindenlauf, 2010; Smith...Sirotenko, 2007; Snyder, Bruulsema, Jensen, \& Fixen, 2009).

Carbon Dioxide: Carbon dioxide from agriculture activities is generated directly from microbial decomposition of organic matter, biomass burning, and on-farm combustion of fossil fuels to run machinery. $\mathrm{CO}_{2}$ is generated indirectly from the manufacturing and transport of various production inputs (e.g., pesticides and fertilizers) and from farm infrastructure (Lal, 2004). Recognized practices to reduce production agriculture $\mathrm{CO}_{2}$ emissions include minimizing external inputs (e.g., pesticides and fertilizers), improving energy efficiency of farm machinery and minimizing their use, improving irrigation practices (through appropriate scheduling and application mechanisms), minimizing fuel-consuming operations, switching fuel sources (from gasoline and diesel to natural gas, ethanol, or biofuel), implementing on-farm renewable energy production (e.g., anaerobic digesters, solar, wind, geothermal or hydroelectric power), establishing biofuel plantations on degraded soils, and reducing loss of soil organic carbon by increasing soil organic matter content via incorporation (e.g., shifting to conservation tillage or no-till, retaining crop residues, avoiding burning residues) (Eagle et al., 2010; Kruger et al., 2010; Lal, 2004; Niggli, Fliebbach, Hepperly, \& Scialabba, 2009; Smith...Sirotenko, 2007).

Carbon Sequestration: The sequestration, or holding, of carbon refers to the transfer of carbon dioxide $\left(\mathrm{CO}_{2}\right)$ from the atmosphere to plants, soils, and fauna in the terrestrial biosphere (Nelson, 2009). Carbon dioxide is the only GHG that can be removed from the atmosphere and sequestered on the farm. Currently, carbon sequestration is the most cost-effective short-term option for reducing $\mathrm{CO}_{2}$ in the atmosphere. However, estimates indicate that carbon sequestration can only make modest contributions to mitigating anthropogenic $\mathrm{CO}_{2}$ (Hutchinson et al., 2007; Lal, 2009; Morgan et al., 2010) and it is important to recognize that soil $\mathrm{C}$ sequestration is nonpermanent, difficult to verify, and not a substitute for, but rather a complement to, GHG emission reduction strategies (Lal \& Follett, 2009). Recommended methods to increase on-farm carbon sequestration include restoring organic (histosol/peat) soils and wetlands, converting cropland to grassland, woodland, or natural ecosystems, implementing agroforestry (e.g., alley cropping, shelterbelts, silvopasture, riparian buffers, and windbreaks), using shortrotation woody crops, switching from annual to perennial crops, using organic amendments including biochar, improving management of rangelands (uncultivated) and pasture (cultivated), using winter cover crops, eliminating or minimizing summer fallow, using diversified crop rotations, and improving irrigation practices to support optimum plant growth (Eagle et al., 2010; Hutchinson et al., 2007; Morgan et al., 2010; Powlson, Whitmore, \& Goulding, 2011). 


\section{Variability of Agriculture Emissions: The Uncertain Science}

The science of agriculture GHG mitigation is inexact and the uncertainties associated with agricultural emissions range between $13 \%$ and 100\% (Meridian Institute, 2011). On-farm agriculture emissions can come from mechanical sources and from nonmechanical sources (Russell, 2011). Generally, mechanical sources of GHGs those associated with purchased energy to run machinery - are easier to estimate than nonmechanical sources. Nonmechanical GHG emissions result from a variety of biochemical processes that occur in soils, air, plants, and animals. The uncertainty of nonmechanical emission sources is due to the dynamic nature of agro-ecosystems, which are influenced by many factors. Specific factors that can influence nonmechanical GHG fluxes from agricultural lands include climate, topography, land use, land cover, soil characteristics, soil management, crop management, livestock management, and input management (Moreau, Adams, Mullinix, Fallick, \& Condon, 2011). The science around agroecosystem GHG emissions is further complicated because agricultural land acts both as a source and a sink for GHGs. This balance between GHG emissions and removal on agriculture land varies over time and space, and current estimates are uncertain (Smith...Sirotenko, 2007).

\section{Agriculture GHG Emission Inventories: One Manages What One Measures}

The measurement, reporting, and verification (MRV) of GHG emissions through inventories is considered fundamental to emissions management and reductions because it quantifies emission rates and provides essential baseline data from which prioritized reduction strategies can be developed (Russell, 2011). Inventories also provide an integral part of the monitoring process by which reduction strategies can be evaluated (British Columiba Ministry of Community Sport and Cultural Development, 2010). The development, compilation, and reporting of GHG emissions are done in accordance with the UNFCCC using the IPCC quantification guidelines (Intergovernmental Panel on Climate Change, 2006). The IPCC guidelines cover categories of emissions by sources and removal by sinks. The GHG Protocol Initiative is another key global agency working to build effective standards for GHG emission accounting and reporting (Greenhouse Gas Protocol, 2011).

National Inventories: In Canada, the National Inventory Report (NIR) is used to account for national GHG emissions to international agencies. It includes agricultural emissions from enteric fermentation, manure management, and direct and indirect emissions from soil (Environment Canada, 2010). In 2008, inventories indicated that Canadian agriculture accounted for approximately $8.5 \%$ of total national GHG emissions. Of the $8.5 \%$ from agriculture, $51 \%$ comes from soils, $35.5 \%$ from enteric fermentation, and 12\% from manure management (Environment Canada, 2010). Agriculture emissions not included in the Canadian NIR were from on-farm fuel consumption (these emissions are accounted for in the Energy sector inventories), embedded emissions in machinery and infrastructure, land-use changes, agri-chemical manufacture and transport, biological fixation by legume-rhizobium association, methane emissions from Canadian rice production, and field burning of crop residues.

Provincial Inventories: In B.C., provincial GHG inventories are conducted using national and international reporting methodologies (BC Ministry of Environment, 2010a). The first, British Columbia Greenhouse Gas Inventory Report 2007, provides the baseline against which subsequent reports will be compared. Similar to the national emission reports, agriculture emissions inventoried include enteric fermentation, manure management, and direct and indirect emissions from soil (BC Ministry of Environment, 2010b). Provincial inventories indicate that agriculture accounts for $3.8 \%$ of total emissions: $50 \%$ from enteric fermentation, $33 \%$ from soils, and $17 \%$ from manure management. The low apparent emissions from agriculture reflect accounting methodologies that do not incorporate agriculture's full contribution to anthropogenic GHG emissions. 
Local Government Inventories: In contrast to provincial, national, and international emissions reporting guidelines, there are no defined protocols for local government monitoring and reporting of GHG emissions associated with agriculture. At the regional level where we live, Metro Vancouver participates in the preparation of the Lower Fraser $V$ alley Emission Inventory that accounts for agriculture GHG estimates (Metro Vancouver, 2007). However, individual municipalities currently conduct assessments of GHG emissions from buildings, transportation, and solid waste only and do not account for agriculture within their Community Energy and Emissions Inventories (CEEIs). Although some municipalities collect data on enteric fermentation, these emissions are described only as "memo items" and are not included in total area emission calculations. As a result, no agriculture emission estimates are accounted for in the total reported emissions from municipalities in British Columbia (BC Ministry of Environment, 2010a). Reasons for agricultural $\mathrm{CH}_{4}$ exclusion from the municipal inventories include (1) emission values used in national estimates for manure management do not reflect variable regional or local environmental conditions; (2) variation in farm practices greatly affects manure emissions; and (3) B.C. lacks systematic observation and measurement of various farm practices. For $\mathrm{N}_{2} \mathrm{O}$, the main reason for exclusion is a lack of information at the local level.

\section{Discussion}

Food system planning is confronted with the daunting challenge of mitigating and adapting to climate change while simultaneously ensuring food security, economic prosperity, community development, human health, and the advancement of sustainable agri-food systems. The uncertain science of agriculture GHG mitigation poses a unique challenge for food system mitigation and adaptation planning. This uncertainty, and the fact that there is no globally applicable list of mitigating practices, highlights the importance for local governments and food system planners to identify regional sources of emissions and factors affecting them and then to identify opportunities for improved efficiencies and prioritize early action items. Furthermore, long-term climate change policy decisions by governments are mandating significant GHG emissions reductions in all sectors of human enterprise. Food system planning that does not address GHG mitigation and adaptation will be vulnerable to anticipated climate changes and to the political, economic, and social repercussions of not doing so.

Ultimately, climate change mitigation within the agricultural sector must occur at the local level through the combined efforts of farmers, nongovernment organizations, communities, scientists, industry, planners, and local governments. Planning for agriculture mitigation requires developing strategies that strengthen agricultural GHG inventories and identifying and prioritizing regionally appropriate actions that reduce GHGs. As part of this, it is essential to conduct research related to agriculture, economics, and policy.

Generally, agriculture GHG emissions inventories tend to give a diminished impression of the sector's impact because many emission sources are either accounted for in other inventories (e.g., on-farm fuel consumption is accounted for in the energy inventory) or not at all (e.g., embedded emissions in machinery and infrastructure). Despite the challenges and uncertainties associated with obtaining agriculture emissions data, not accounting for them in municipal inventories means there is no baseline data from which prioritized and place-specific reduction strategies can be identified, let alone promoted. Furthermore, excluding agriculture from GHG inventories suggests to the local government and the agriculture communities within their jurisdiction that GHG mitigation in agriculture is not pertinent and pressing, when indeed it is.

A number of important agricultural research questions that need to be answered have been identified (Pretty et al., 2010) and some that are specific to mitigation include exploring (1) how can global food production be increased while simultaneously reducing emissions, (2) what do low input production or carbon-neutral systems look like and how can they be designed, and (3) how can 
crop breeding, new technologies, improved agronomic practices, and integrated cropping systems improve mitigation efforts?

Economic drivers, barriers, and implications of climate change mitigation need to be explored further at local levels. Financial incentives, investment policies, and other market mechanisms (such as carbon trading, carbon taxes, offset markets, payment for environmental services, and preferential support for local agri-food systems) are examples of tools and strategies that may assist farmers in adopting regionally appropriate mitigation practices that may be otherwise costprohibitive. However, research is vitally needed to determine the potential impacts of such strategies and to understand under what circumstances such strategies achieve the greatest economic, societal, and environmental good. Early investment in mitigation and adaptation actions is essential to building long-term resilience of the sector (Meridian Institute, 2011).

Policy plays an essential role in enabling climate change mitigation within the agricultural sector. However, understanding and navigating policy and regulatory constructs are supremely complicated due to the interacting influences and directives of policies (some climate-focused and others not) that directly affect agriculture (see Moreau, Moore, \& Mullinex, 2012, in this issue). Analyzing policy at the local level is critical to agricultural climate change planning in order to identify key influencing policies that will directly or indirectly affect mitigation strategies (Smith...Towprayoon, 2007). Furthermore, policy synergies, conflicts, and contradictions need to be understood.

\section{Conclusions}

The agricultural sector is vital to sustainable human existence, and therefore we cannot ignore the real and substantial role that agriculture plays in GHG emissions nor the potentially catastrophic effects on food security and sustainability if planning for the sector does not consider climate changes. In summarizing the scientific information relating to agriculture GHG mitigation, we hope to have presented and framed the pertinent information necessary for local food system planners to begin to make planning decisions that are informed and appropriate relative to climate change and agrifood systems. We also hope that this review and subsequent discussions will prompt local agri-food system planners to advocate for the information and resources they need to accomplish the critically important task of promoting the mitigation of production agriculture's GHG emissions at the local level. Finally, because the science around production agriculture and climate change denies conclusive direction, we cannot delay: time is of the essence. Community and regional planners must begin to address sustainable agri-food systems and greenhouse gas mitigation.

\section{Acknowledgements}

We are grateful to Erik Karlsen, Arthur Fallick, Caitlin Dorward, and Theresa Dunystee for their technical advice and feedback.

\section{References}

British Columbia Ministry of Community, Sport and Cultural Development. (2010). Community-wide climate action planning. Retrieved from http://www.toolkit.bc.ca/cw-actionplanning

British Columbia Ministry of Environment. (2010a). Technical methods and guidance document for 2007 CEEI reports: Community Energy and Emissions Inventory (CEEI) Initiative. Retrieved from http://www.env.gov.bc.ca/cas/mitigation/ceei/ CEEI TechMethods Guidance final.pdf

British Columbia Ministry of Environment. (2010b). British Columbia Greenhouse Gas Inventory report.

Retrieved April 4, 2011, from http://www.env.gov.bc.ca/cas/mitigation/ghg inventory/index.html

Climate Action Initiative. (2011). Climate Action Initiative, BC Agriculture \& Food. Retrieved August 23, 2011, from http://www.bcagclimateaction.ca

"Common Questions About $\mathrm{MtCO}_{2}$." (2008). MtCO2e - Metric Tonne Carbon Dioxide Equivalent. Retrieved Feb. 28, 2012, from http://www.mtco2e.com

Eagle, A. J., Henry, L. R., Olander, L. P., HaugenKozyra, K., Millar, N., \& Roberton, G. P. (2010). Greenhouse gas mitigation potential of agricultural land management in the United States: A synthesis of the 
literature. Technical Working Group on Agricultural Greenhouse Gases (T-AGG) Report. Nicholas Institute for Environmental Policy Solutions. Retrieved from http://nicholasinstitute.duke.edu/ ecosystem/land/TAGGDLitRev

Environment Canada. (2010). National Inventory Report 1990-2008: Greenhouse gas sources and sinks in Canada. Retrieved April 2, 2011, from http://www.ec.gc.ca/Publications/default.asp?lang $=\mathrm{En} \& x m l=492 \mathrm{D} 914 \mathrm{C}-2 \mathrm{EAB}-47 \mathrm{AB}-\mathrm{A} 045-$ C62B2CDACC29

Forster, P., Ramaswamy, V., Artaxo, T., Berntsen, R., Betts, D., Fahey,...Van Dorland, R. (2007). Changes in atmospheric constituents and in radiative forcing. In S. Solomon, D. Qin, M. Manning, Z. Chen, M. Marquis, K. B. Averyt, M. Tignor, \& H. L. Miller (Eds.). Climate Change 2007: The Physical Science Basis (Contribution of Working Group I to the Fourth Assessment Report of the Intergovernmental Panel on Climate Change) (pp. 129-234). Cambridge, U.K.: Cambridge University Press. Retrieved from http://www.ipcc.ch/publications and data/public ations ipcc fourth assessment report wg1 report the physical science basis.htm

Greenhouse Gas Protocol, The. (2011). The Greenhouse Gas Protocol Initiative. Retrieved April 7, 2011, from http://www.ghgprotocol.org

Holt-Giménez, E. (2002). Measuring farmers' agroecological resistance after Hurricane Mitch in Nicaragua: A case study in participatory, sustainable land management impact monitoring. Agriculture, Ecosystems \& Environment, 93(1-3), 87-105. http://dx.doi.org/10.1016/S0167-8809(02)00006-3

Hutchinson, J. J., Campbell, C. A., \& Desjardins, R. L. (2007). Some perspectives on carbon sequestration in agriculture. Agriculture and Forest Meteorology, 142(2-4), 288-302.

http://dx.doi.org/10.1016/j.agrformet.2006.03.030 Intergovernmental Panel on Climate Change (IPCC). (2006). 2006 IPCC guidelines for National Greenhouse Gas Inventories. Retrieved July 2, 2011, from http://www.ipcc-nggip.iges.or.jp/public/2006gl/

Intergovernmental Panel on Climate Change (IPCC). (2007a). Summary for Policymakers. In S. S. Solomon, D. Qin, M. Manning, Z. Chen, M. Marquis, K. B. Averyt, M.Tignor \& H. L. Miller (Eds.). Climate Change 2007: The Physical Science Basis
(Contribution of Working Group I to the Fourth Assessment Report of the Intergovernmental Panel on Climate Change). Cambridge University Press, Cambridge, U.K., and New York, NY, USA. Retrieved from http://www.ipcc.ch/publications and data/ar4/wg1/en/spm.html

Intergovernmental Panel on Climate Change (IPCC). (2007b). Climate Change 2007: Synthesis Report. In S. S. Solomon, D. Qin, M. Manning, Z. Chen, M. Marquis, K. B. Averyt, M.Tignor \& H. L. Miller (Eds.). Climate Change 2007: The Physical Science Basis (Contribution of Working Group I to the Fourth Assessment Report of the Intergovernmental Panel on Climate Change). Cambridge University Press, Cambridge, U.K., and New York, NY, USA. Retrieved from http://www.ipcc.ch/publications and data/ar4/syr/en/main.html

International Fertilizer Association (IFA) \& the Food and Agriculture Organization of the United Nations (FAO). (2001). Global estimates of gaseous emissions of $\mathrm{NH}_{3}, \mathrm{NO}$ and $\mathrm{N}_{2} \mathrm{O}$ from agricultural land. Rome: United Nations FAO. Retrieved from http://www.fao.org/docrep/004/y2780e/ y2780e00.HTM

Jenkinson, D. (2010). Climate change: A brief introduction for scientists and engineers or anyone else who has to do something about it. Rothamsted Research. Retrieved from http://www.rothamsted.ac.uk/Research/ Centres $/$ Content.php?Section $=$ Research\&Page $=$ ClimateChangeReview

Klein, R., Schipper, L., \& Dessai, S. (2005). Integrating mitigation and adaptation into climate and development policy: Three research questions. Environmental Science and Policy 8(6), 579-588.

http://dx.doi.org/10.1016/j.envsci.2005.06.010

Kruger, C., Yorgey, G., Chen, S., Collins, H., Feise, C., Frear, C.,...Stöckle, C. (2010). Climate friendly farming: Improving the carbon footprint of agriculture in the Pacific Northwest (CSANR Research Report 2010001). Washington State University. Retrieved July 2, 2011, from http://csanr.wsu.edu/pages/Climate Friendly Farming Final Report/

Lal, R. (2004). Carbon emission from farm operations. Environment International, 30(7), 981-990. http://dx.doi.org/10.1016/j.envint.2004.03.005

Lal, R. (2009). Sequestering atmospheric carbon dioxide. Critical Reviews in Plant Science, 28(3), 90-96. http://dx.doi.org/10.1080/07352680902782711 
Lal, R., \& Follett, R. (2009). Soil carbon sequestration and the greenhouse effect (2nd ed.). Madison, WI, USA: Soil Science Society of America Special Publication.

Meridian Institute. (2011, June). Agriculture and climate change: A scoping report. Washington, D.C., USA: Author. Retrieved from http://www.climateagriculture.org/

Metro Vancouver. (2007). 2005 Lower Fraser V alley air emissions inventory \& forecast and backcast: Executive Summary. Retrieved from http://www.metrovancouver.org/about/ publications/Publications/ExecSummary 2005 LFV.pdf

Moreau, T. L., Adams, T., Mullinix, K., Fallick, A., \& Condon, P. M. (2011). Recommended practices for climate-smart urban and peri-urban agriculture. AESOP 2nd European Sustainable Food Planning Conference Proceedings.

Moreau, T. L., Moore, J., \& Mullinix, K. (2012). Planning for climate action in British Columbia, Canada: Putting agricultural greenhouse gas mitigation on local government agendas. Journal of Agriculture, Food Systems, and Community Development. Advance online publication. http://dx.doi.org/10.5304/jafscd.2012.022.008

Morgan, J. A., Follett, R. F., Allen, L. H., Del Grosso, S., Derner, J. D., Dijkstra, F.,...Schoeneberger, M. M. (2010). Carbon sequestration in agricultural lands of the United States. Journal of Soil and Water Conservation, 65(1), 6A-13A. http://dx.doi.org/10.2489/jswc.65.1.6A

Nelson, G. C. (Ed.). (2009). Agriculture and climate change: An agenda for negotiation in Copenhagen. Washington, D.C., USA: International Food Policy Research Institute. Retrieved from http://www.ifpri.org/ publication/agriculture-and-climate-change

Niggli, U., Fliebbach, A., Hepperly, P., \& Scialabba, N. (2009). Low greenhouse gas agriculture: Mitigation and adaptation potential of sustainable farming solutions. Food and Agriculture Organization of the United Nations.

Paustian, K., Babcock, B. A., Kling, C., Hatfield, J., Lal, R., McCarl, B. A.,...Zilberman, D. (2004). Agricultural mitigation of greenhouse gases: Science and policy options. CAST (Council on Agricultural Science and Technology). Retrieved from http://www.netl.doe.gov/publications/ proceedings $/ 01 /$ carbon seq/4C2.pdf
Pimm, S. L. (1984). The complexity and stability of ecosystems. Nature, 307(5949), 321-326. http://dx.doi.org/10.1038/307321a0

Powlson, D. S., Whitmore, A. P., \& Goulding, K. W. T. (2011). Soil carbon sequestration to mitigate climate change: A critical re-examination to identify the true and the false. European Journal of Soil Science, 62(1), 42-55. http://dx.doi.org/10.1111/j.13652389.2010.01342.x

Pretty, J., Sutherland, W. J., Ashby, J., Auburn, J., Baulcombe, D., Bell, M.,...Pilgrim, S. (2010). The top 100 questions of importance to the future of global agriculture. International Journal of Agricultural Sustainability, 8(4), 219-236. http://dx.doi.org/10.3763/ijas.2010.0534

Russell, S. (2011). Corporate greenhouse gas inventories for the agricultural sector: Proposed accounting and reporting steps (WRI working paper). Washington, D.C., USA: World Resources Institute. Retrieved from http://www.wri.org/publication/corporate-ghginventories-for-the-agricultural-sector

Scialabba, N., \& Muller-Lindenlauf, M. (2010). Organic agriculture and climate change. Renewable Agriculture and Food Systems, 25(2), 158-169. http://dx.doi.org/10.1017/S1742170510000116

Smith, P., Martino, D., Cai, Z., Gwary, D., Janzen, H., Kumar, P., McCarl, B.,...Sirotenko, O. P. (2007). Agriculture. In B. Metz, O. R. Davidson, P. R. Bosch, R. Dave, L. A. Meyer (Eds.), Climate Change 2007: Mitigation, Contribution of Working Group III to the Fourth Assessment Report of the Intergovernmental Panel on Climate Change (pp. 497-540). Cambridge, United Kingdom, and New York: Cambridge University Press.

Smith, P., Martino, D., Cai, Z., Gwary, D., Janzen, H., Kumar, P., McCarl, B.,... Towprayoon, S. (2007). Policy and technological constraints to implementation of greenhouse gas mitigation options in agriculture. Agriculture, Ecosystems \& Environment, 118(1-4), 6-28. http://dx.doi.org/10.1016/j.agee.2006.06.006 Smith, P., Martino, D., Cai, Z., Gwary, D., Janzen, H., Kumar, P.,...Smith, J. (2008). Greenhouse gas mitigation in agriculture. Philosophical Transactions of the Royal Society B: Biological Sciences, 363(1492), 789 813. http://dx.doi.org/10.1098/rstb.2007.2184 
Smith, W. N., Grant, B. B., Desjardins, R. L., Worth, D., Li, C., Boles, S. H., \& Huffman, E. C. (2010). A tool to link agricultural activity data with the DNDC model to estimate GHG emission factors in Canada. Agriculture, Ecosystems \& Environment, 136(3-4), 301-309.

http://dx.doi.org/10.1016/j.agee.2009.12.008
Snyder, C. S., Bruulsema, T. W., Jensen, T. L., \& Fixen, P. E. (2009). Review of greenhouse gas emissions from crop production systems and fertilizer management effects. Agriculture, Ecosystems \& Environment, 133(3-4), 247-266.

http://dx.doi.org/10.1016/j.agee.2009.04.021 